\title{
Growth and survival of post-larval giant tiger shrimp Penaeus monodon feeding on mangrove leaf litter biofilms
}

\author{
Charles Gatune ${ }^{1,2,3, *}$, Ann Vanreusel ${ }^{1}$, Renison Ruwa ${ }^{2}$, Peter Bossier ${ }^{4}$, \\ Marleen De Troch ${ }^{1}$ \\ ${ }^{1}$ Ghent University, Biology Department, Marine Biology, Campus Sterre, Krijgslaan 281-S8, 9000, Ghent, Belgium \\ ${ }^{2}$ Kenya Marine and Fisheries Research Institute, PO Box 81651-80100, Mombasa, Kenya \\ ${ }^{3}$ Karatina University, School of Natural Resources \& Environmental Studies, PO Box 1957-10101, Karatina, Kenya \\ ${ }^{4}$ Ghent University, Faculty of Bioscience Engineering, Laboratory of Aquaculture and Artemia Reference Centre, Rozier 44, \\ 9000, Ghent, Belgium
}

\begin{abstract}
Biofilm associated with decomposing mangrove leaf litter is a food source for shrimp post-larvae (PL). PL of giant tiger shrimp Penaeus monodon foraging on leaf litter of Rhizophora mucronata with developing biofilm at 1, 3, 4, 6, and $8 \mathrm{wk}$ of decomposition were tested for specific growth rate (SGR, \%) and percentage survival (SR, \%). Biofilm was analyzed for species composition, abundance, and biomass of microalgae and epifauna. Microalgal biomass increased with the progress of litter decomposition. Diatoms, especially Navicula sp. and Nitzschia sp., dominated the first 6 wk of litter decomposition with a percentage cover of 88 and $99 \%$ during the third and fourth weeks, respectively. Cyanobacteria dominated in the 8 wk old biofilm with $61 \%$ cover. Copepods dominated the epifauna during the first $3 \mathrm{wk}$ of litter decomposition. In the 4 to $5 \mathrm{wk}$ old litter, polychaetes were most abundant whereas nematodes were dominant in litter that had decomposed for $8 \mathrm{wk}$. PL foraging on 4 wk old litter had a higher SGR $(1.6 \pm 0.5 \%)$ and SR $(39.8 \pm$ $4.8 \%$ ) coincident with the maximum abundance of microalgae and epifauna. The study illustrated that nutritionally rich biofilm for PL shrimp is: (1) developed during the fourth week of mangrove leaf litter decomposition and is dominated by diatoms, polychaetes, harpacticoid copepods, and oligochaetes; and (2) limited by the collapse of the epifauna and subsequent colonization by cyanobacteria in mangrove leaf litter decomposed beyond $4 \mathrm{wk}$.
\end{abstract}

KEY WORDS: Mangrove $\cdot$ Decomposition $\cdot$ Biofilm $\cdot$ Microalgae $\cdot$ Epifauna $\cdot$ Shrimp

\section{INTRODUCTION}

The natural diet of penaeid post-larval (PL) shrimp has been characterized at different stages of the life cycle from nauplius, protozoea, mysis to PL (Dall et al. 1990, Rothlisberg 1998). Protozoea are typically herbivorous, while the mysis and PL become increasingly carnivorous. However, the PL are opportunistic feeders; for example, if diatoms dominate the environment, they will also dominate the diet of the shrimp (Preston et al. 1992). The composition and the diversity of microalgae may both directly and indirectly determine the nutritional quality of the natural food for PL. For instance, diatoms have a positive effect on growth and survival (Brown \& Farmer 1994, Burford 1997, Ying et al. 2000) as they are rich in polyunsaturated fatty acids (PUFAs) (Parrish et al. 2000), which positively affect growth and metamorphosis in crustacean larvae, and survival and resilience to stressful conditions in juveniles (Read 1981, 
Bell et al. 1984, Lavens \& Sorgeloos 2000). Differences in the microalgal taxonomic composition rather than size or shape appear to be the critical factor (Rothlisberg 1998). Penaeus semisulcatus larvae achieve better growth when fed Chlorophyta of the species Tetraselmis suecica rich in proteins and essential fatty acids (D'Souza \& Kelly 2000). The nontoxic blue-green alga Trichodesmium sp. was ingested by larvae of $P$. merguiensis, although it did not support growth or survival (Preston et al. 1998). Burford (1997) and Primavera (1998) suggested a variety of microalgal indicators, such as abundance and species diversity, as proxies for the actual food conditions and water quality (Casé et al. 2008) in shrimp culture ponds.

Penaeid PL also eat a wide variety of small invertebrates and plant material (Chen \& Chen 1992, Rothlisberg 1998, Nunes \& Parsons 2000). Prey in the natural diet of juvenile $P$. esculentus in seagrass beds include gastropod species, bivalves, crustaceans, and polychaetes. The epifauna is high in protein content and PUFA, and relatively low in carbohydrate (Dall et al. 1991). Polychaetes of the families Spionidae, Capitellidae, Eunicidae, Nereidae, Pilargidae, and Seballidae have been used in penaeid shrimp predation experiments, especially with $P$. subtilis (Nunes \& Parsons 2000).

The importance of mangrove leaf litter as food for shrimp larvae may be linked to the associated periphytic biofilm. The present study defined the periphytic biofilm developing on the decomposing mangrove litter as a network of primary (microalgae) and secondary (epifauna) trophic levels mediated by a microbial loop (bacteria) (Azim \& Wahab 2005). Stable isotope studies have demonstrated that giant tiger shrimp $P$. monodon feed on phytoplankton and epiphytic microalgae in a riverine mangrove forest in Guimaras (central Philippines; Primavera 1996). In the Itamaraca estuary, Brazil, Schwamborn et al. (2002) found penaeid PL to have the highest carbon isotope delta values $\left(\delta^{13} \mathrm{C}\right)$ among the decapod larvae, indicating a negligible contribution of mangrove carbon to their nutrition.

PL feeding response may be influenced by the litter and biofilm palatability, which may be influenced negatively by the increasing level of tannins in the decomposing mangrove leaves (Rajendran \& Kathiresan 2000). Direct observations on penaeid PL (Primavera 1996) and other benthic invertebrates (Bouillon et al. 2002) showed a reduced preference for mangrove-derived carbon compared to local and imported algal sources. Ronnback et al. (2002) observed that the distribution of juvenile $P$. indicus did not vary in abundance between sediments of low and high organic content. However, juvenile penaeid shrimp aggregate around mangrove litter colonized by bacteria (Rajendran \& Kathiresan 2004, 2007). On average, 60 to $75 \%$ of nitrogen and 20 to $40 \%$ of carbon in highly decomposed mangrove leaf litter derive from heterotrophic bacteria and not from the remaining plant tissues (Tremblay \& Benner 2006). In natural systems, bacteria may not occur as a separate functional or ecological entity but are present in combination with other microbiota forming benthic and epiphytic biofilms or as a flocculated mass in suspension (Burford et al. 2003, Azim \& Wahab 2005).

The biological components of the biofilm and their nutritive value to PL in culture ponds have not been studied, although it is pivotal information to manage the mangrove litter in shrimp ponds. We hypothesized that the food value of mangrove leaf litter and the associated biofilm to PL depends on the assemblage and biomass of microalgae and epifauna as the decomposition of the mangrove litter progresses. We therefore investigated the major taxa of microalgae and invertebrate fauna colonizing the decomposing mangrove litter of Rhizophora mucronata and their application as diet for PL of $P$. monodon.

\section{MATERIALS AND METHODS}

\section{Study site}

The study was carried out in a mangrove forest and shrimp ponds at the mangrove conservation farm (Majaoni Silvofishery) located in Mtwapa Creek on the northern coast of Kenya $\left(3^{\circ} 57^{\prime} \mathrm{S}, 39^{\circ} 42^{\prime} \mathrm{E}\right)$. This site was used to incubate mangrove litter in ponds of 75 to $100 \mathrm{~cm}$ water depth. Mtwapa Creek is characterized by a reforested mangrove forest dominated by Rhizophora mucronata. PL of Penaeus indicus and $P$. monodon are commonly fished within this creek.

\section{Test organism}

PL of P. monodon, aged between 15 and $25 \mathrm{~d}$ from the time of hatching (PL 15-25) and hatched from the same brooder (cohort), were obtained from the Alphakrust shrimp hatchery at Mafia Island, Tanzania (www.alphaafrica.com). They were transported in plastic bags with a pure oxygen headspace for not more than $6 \mathrm{~h}$ and acclimatized to local conditions in a culture tank for $1 \mathrm{wk}$ before the start of the ex- 
periment. During the acclimatization period, the PL were fed on a shrimp larvae compound feed (CP) imported from India (Higashimaru zoea to PL 20 feed ${ }_{i}$ crude protein over $52 \%$, see www.aquafeed. com/documents/1254938830_1.pdf).

\section{Litter incubation and biofilm biomass}

Senescent mangrove leaves (hereafter referred to as litter), which had just turned yellow-brown and dropped from the trees, were dried in the shade to a constant weight and incubated in water hanging on 3 ropes (representing 3 replicates) in a shrimp pond, not stocked with shrimps, for a period of $8 \mathrm{wk}$. The incubation of the leaves was staggered by $1 \mathrm{wk}$ to provide litter of the same age to the different treatments throughout the experiment. Given that the litter ropes were set up in triplicates, the set-up ultimately used 24 ropes to accommodate the $8 \mathrm{wk}$ duration of litter incubation. However, to ensure that the biofilm fed to the shrimp was replenished every $4 \mathrm{~d}$, the litter was harvested, in replicates and pooled, every $4 \mathrm{~d}$ within the same week to ensure that the week factor was maintained. The associated biofilm was also sampled by carefully scraping 3 leaves from each rope replicate. To estimate the biomass, the biofilm was dried in an oven at $70^{\circ} \mathrm{C}$ for $48 \mathrm{~h}$ and quantified as weight per unit leaf surface area.

\section{Microalgae and epifauna}

Litter was sampled weekly in triplicate by pooling 3 decomposing leaves per replicate. The biofilm was gently washed from the surface of the decomposing litter with a known volume of filtered sea water and preserved in 2\% Lugol's iodine solution (1:2 iodine: iodide: glacial acetic acid solution). Microalgae were classified and counted after first diluting each replicate sample 5 to 10 times; 5 sub-replicates of $0.02 \mathrm{ml}$ were then sub-sampled and examined under an inverted microscope to determine microalgal abundance (cells ${ }^{-1}$ ).

To assess the microalgal biomass, mangrove leaf litter was sampled weekly in triplicate by pooling 3 leaves per sample. The periphytic biofilm was gently scraped from the surface of the litter with a known volume of filtered sea water and filtered through a glass fiber filter (GF/F, $0.45 \mu \mathrm{m}$ mesh, $47 \mathrm{~mm}$ diameter). The surface area of both sides of the leaf was determined in order to convert the algal biomass from chlorophyll a ( $\mathrm{chl} \mathrm{a}$ ) $\mathrm{gg} \mathrm{l}^{-1}$ to $\mathrm{mg} \mathrm{cm}^{-2}$ of the total leaf surface. Phytopigments were extracted from the biofilm after adding $10 \mathrm{ml} 90 \%$ acetone to the lyophylized GF/F at $4^{\circ} \mathrm{C}$ in the dark, and the supernatant was analyzed for $\mathrm{chl} a$ according to the modified protocol of Granger \& Lizumi (2001).

We examined the epifauna, which included both the meiofauna (metazoans that pass through a $1 \mathrm{~mm}$ sieve and are retained on a $38 \mu \mathrm{m}$ sieve) and macrofauna (organisms retained on a $1 \mathrm{~mm}$ sieve). Litter was sampled weekly in triplicate by pooling 9 decomposing leaves per replicate in a plastic bag. Each group of decomposing leaves was immediately mixed with $8 \% \mathrm{MgCl}_{2}$ to shock the attached epifauna, thoroughly agitated, and subsequently sieved through $1 \mathrm{~mm}$ and $38 \mu \mathrm{m}$ sieves. The sieved fauna was gently washed from the $38 \mu \mathrm{m}$ sieve with a soft spray of filtered fresh water, preserved in $4 \%$ formalin, and stained with a few drops of $1 \%$ Rose Bengal solution. Epifauna was identified and counted at the highest possible taxon level using a binocular microscope and recorded as number of individuals per $\mathrm{cm}^{2}$ of leaf surface.

\section{Species diversity and evenness}

The Shannon-Wiener index $\left(H^{\prime}\right)$ and equitability index $(\mathrm{EH})$ were used to estimate the microalgal and epifaunal community diversity and evenness based on the natural log (Shannon 1948), according to the following formulas:

$$
\begin{gathered}
\mathrm{H}^{\prime}=-\sum_{\mathrm{i}=1}^{\mathrm{n}} \mathrm{p}_{\mathrm{i}} \ln \mathrm{p}_{\mathrm{i}} \\
\mathrm{EH}=\frac{H^{\prime}}{\ln S}
\end{gathered}
$$

where $S$ is the total number of species in the community; $p_{i}$ is the proportion of $S$ made up by the $i$ th species. Species equitability or evenness $(\mathrm{EH})$ was interpreted within the range of 0 (dominance by a single species) to 1 (many species present in equal numbers).

\section{Feeding experiment}

PL 15-25 of P. monodon were starved for $24 \mathrm{~h}$ before the start of the experiment and then stocked for $16 \mathrm{~d}$ into $70 \mathrm{l}$ circular laboratory tanks in triplicate at a density of $2 \mathrm{PL} \mathrm{l}^{-1}$. The culture water was obtained from a reservoir tank and treated by first passing through a sand filter, then through a cartilage filter and disinfected by UV exposure. The cul- 
ture water was replenished by adjusting the flowthrough system to achieve a water exchange rate of $50 \% \mathrm{~d}^{-1}$. Dissolved oxygen was maintained by continuously aerating water in both reservoir and experimental tanks through airstones. The following food treatments were tested: (1) mangrove leaf litter with biofilm at $1,3,4,6$, and 8 wk of decomposition; (2) commercial compound feed $(\mathrm{CP})_{i}$ and (3) no food, as a control treatment. After removing the old batch of leaf litter from the tank, the PL were supplied every $4 \mathrm{~d}$ with new mangrove leaf litter, originating from the stock of leaves in the incubation pond, to maintain a litter density not exceeding $0.5 \mathrm{~g} \mathrm{l}^{-1}$ (Hai \& Yakupitiyage 2005). The litter density was translated to supply an amount of dry biofilm biomass which would provide a feeding rate of $10 \%$ dry body weight. To estimate the dry weight, prior to the feeding experiment, $10 \mathrm{PL}$ were sampled at random and dried in an oven at $70^{\circ} \mathrm{C}$ for $48 \mathrm{~h}$ and later weighed. This dry weight was extrapolated to the total PL stocked in the experimental tanks and used to calculate the daily proportion of the dry food. As all food sources in different treatments were provided in the same biomass, the same feeding rate of $10 \%$ dry body weight was used for the $\mathrm{CP}$ feed. Food items were offered twice a day (morning and afternoon) after removing the remaining food, and doubled every $3.5 \mathrm{~d}$. PL were sampled weekly for specific growth rate (SGR, \%) and at the end of the experiment for percentage survival (SR, \%).

The growth and survival indices were calculated using the following formulae (Busacker et al. 1990),

$$
\begin{gathered}
\mathrm{SGR} \%=\frac{\ln \left(\mathrm{BW}_{t}\right)-\ln \left(\mathrm{BW}_{0}\right)}{T} \times 100 \\
\mathrm{SR} \%=\frac{N_{t}}{N_{0}} \times 100
\end{gathered}
$$

where SGR is the specific growth rate $\left(\% \mathrm{BW} \mathrm{d}^{-1}\right)$; $\mathrm{BW}_{t}$ is the final body wet weight $(\mathrm{g})_{;} \mathrm{BW}_{0}$ is the initial body wet weight $(\mathrm{g})_{i} T$ is duration of the experiment (days); SR is the survival (in \%); $N_{t}$ is the number of shrimp collected at sampling time $t_{i} N_{0}$ is the number of shrimp initially stocked. The wet weight was based on sampling groups of 70 individuals. The following water quality parameters were measured weekly: temperature, dissolved oxygen, $\mathrm{pH}$, salinity, and total ammonium nitrogen (TAN). Temperature, dissolved oxygen, and $\mathrm{pH}$ were measured using meters, salinity was measured using a refractometer, and TAN was analyzed in the laboratory according to Eaton et al. (2005).

\section{Data analysis}

Univariate statistical analyses (ANOVA) were conducted with Statistica 7.0 software. All data were checked for normality and variance homogeneity requirements for parametric analysis. Data which did not meet normality requirements after being transformed were analyzed non-parametrically (KruskalWallis ANOVA and median test). Multidimensional scaling (MDS) and analysis of similarity (ANOSIM) were used to compare similarity in the distribution of target parameters using Primer 6.0 software (Clarke \& Gorley 2006).

\section{RESULTS}

\section{Biofilm and microalgal biomass}

Biofilm increased in both quantitative and chl a estimated biomass throughout the period of litter decomposition. The highest biofilm biomass was in the litter decomposed for $8 \mathrm{wk}$, which was significantly different from the biomass on leaf litter decomposed for less than 6 wk (1-way ANOVA: F6, $14=$ $145.43, \mathrm{p}<0.05$ and Tukey post hoc $\mathrm{p}<0.05$ ). Microalgal biomass on the litter decomposed for 1 and $2 \mathrm{wk}$ (Tukey post hoc $\mathrm{p}<0.05$ ). Biofilm on litter had significantly higher biomass of microalgae $(294.07 \pm$ $\left.0.79 \mathrm{\mu g} \mathrm{l}^{-1} \mathrm{chl} a\right)$ than the pond water $(0.79 \pm 0.83 \mu \mathrm{g}$ $\mathrm{l}^{-1} \mathrm{chl} \mathrm{a}$ ) throughout the incubation period ( $\mathrm{p}<0.05$; see Fig. 2a).

\section{Taxonomic composition and species diversity of microalgae}

Among the microalgae, 32 species were identified including 14 diatoms, 8 cyanobacteria, 7 dinoflagellates, 1 coccolith, and 1 flagellate species. Compared to diatoms and cyanobacteria, dinoflagellates, coccoliths, and flagellates had a low cover of $<10 \%$ during the entire period of litter decomposition. Diatoms dominated the biofilm during the first $6 \mathrm{wk}$ of litter decomposition, with a relative cover of 88 and $99 \%$ during Weeks 3 and 4, respectively. Among the diatom species, Navicula sp. dominated the first $4 \mathrm{wk}$ of decomposition, reaching a maximum proportional cover of $90.8 \%$ during Week 3, whereas Nitzschia sp. dominated the later period of decomposition with a maximum cover between 64.2 and $78.7 \%$ during Weeks 5 and 6. Cyanobacteria exhibited lower abun- 
dance during the early period of decomposition but recorded a sharp increase during Week 8 , with a percentage cover of $61 \%$, which exceeded the cover of diatoms (38\%). Among the cyanobacteria, Microcystis sp. dominated the $8 \mathrm{wk}$ old litter with a proportional cover of $55.3 \%$. The lowest microalgal diversity was recorded during Weeks 3, 4, and 5 (Table 1). The microalgal community differed significantly in the different weeks of litter decomposition (ANOSIM: $\mathrm{R}=0.602 ; \mathrm{p}<0.05 ;$ Fig. 1a).

\section{Microalgal species abundance}

Diatoms varied significantly in abundance during the $8 \mathrm{wk}$ of litter decomposition (Kruskal-Wallis test, $\left.H_{6,21}=13.26, \mathrm{p}<0.05\right)$, with a maximum abundance in Week 3 due to the high densities of Navicula sp. and in Week 6 due to Nitzschia sp. (Fig. 2c). Cyanobacteria exhibited lower abundance during the early period of litter decomposition but recorded a sharp increase during Week 8, exceeding the abundance of diatoms. Microcystis sp. dominated the cyanobacteria (Fig. 2d). Peridinium sp. dominated the dinoflagellates during Week 6 (Fig. 2e).

\section{Epifauna diversity and abundance}

We identified 19 major taxa of epifauna on the epiphytic biofilm (Table 2). The epifaunal species colonizing the biofilm differed significantly in the different weeks of litter decomposition (ANOSIM: $\mathrm{R}=0.887$; $\mathrm{p}<0.05$; Fig. 1b). Copepoda dominated the epifauna, colonizing the biofilm during the first 3 wk of litter decomposition with a proportional percentage cover

Table 1. Proportional assemblage ( $P_{i}$ in Eq. 1) of microalgae in biofilm developing on Rhizophora mucronata litter at different stages of decomposition. All values, except diversity index and species evenness, are given in percentages

\begin{tabular}{|c|c|c|c|c|c|c|c|c|}
\hline & \multirow{2}{*}{ Taxon } & & & & \multirow{2}{*}{$\begin{array}{c}\text { Week } \\
4\end{array}$} & \multirow[b]{2}{*}{5} & \multirow[b]{2}{*}{6} & \multirow[b]{2}{*}{8} \\
\hline & & 1 & 2 & 3 & & & & \\
\hline \multirow[t]{15}{*}{ Diatoms } & Nitzschia closterium & 13.3 & 10.2 & 6.1 & 7.8 & 78.7 & 64.2 & 32.1 \\
\hline & Nitzschia sp. & 9.6 & 1.1 & 0.2 & 89.2 & & & \\
\hline & Navicula sp. & 51.8 & 73.3 & 90.8 & & 7.2 & 23.7 & 5.7 \\
\hline & Pseudonitzschia sp. & 2.4 & 0.6 & & & 0.2 & & 0.1 \\
\hline & Rhyosolenia sp. & 3.6 & & & & & & \\
\hline & Pleurosigma sp. & 2.4 & 3.4 & 2.3 & 1.7 & 0.6 & & 0.2 \\
\hline & Leptocylindricus sp. & & & 0.2 & & & & \\
\hline & Coscinodiscus sp. & 1.2 & & & 0.4 & 0.6 & 0.1 & \\
\hline & Thallasionema nitzchoides & & & & & 0.2 & & \\
\hline & Astrionella sp. & 2.4 & & & & 0.2 & 0.1 & \\
\hline & Gunardia sp. & & & & & 0.7 & & \\
\hline & Chaetoceros sp. & & & & & & 0.3 & \\
\hline & Thallasiosira sp. & 1.2 & & & & & 0.1 & \\
\hline & Fraglaria sp. & & 0.6 & & & & & 0.1 \\
\hline & Halsea sp. & & 5.1 & & & & & \\
\hline \multirow[t]{8}{*}{ Cyanobacteria } & Oscillatoria sp. & & & 0.2 & & 9.3 & 3.5 & 2.4 \\
\hline & Anabaena sp. & 4.8 & 0.6 & & & & 1.3 & 1.0 \\
\hline & Microcysts sp. & & & & & & 1.7 & 55.3 \\
\hline & Lyngbya sp. & & & & & & & 0.5 \\
\hline & Snowella lacustris & & & & & & & 1.3 \\
\hline & Amphizolenia sp. & & & & & 0.4 & 0.1 & \\
\hline & Chroccococus sp. & & & & & & & 0.1 \\
\hline & Schizothrix culcicola & & & & & & & 0.1 \\
\hline \multirow{7}{*}{ Dinoflagellates } & Dinophysis sp. & 2.4 & & & & & & \\
\hline & Ceratium sp. & 1.2 & & & & & & \\
\hline & Peridinium sp. & & & & 0.4 & 0.2 & 1.6 & 0.3 \\
\hline & Protoperidinium sp. & 3.6 & 2.8 & & 0.2 & 0.6 & 0.3 & \\
\hline & Prorocentrum sp. & 2.3 & & & & 0.2 & 0.1 & \\
\hline & Scrippsiella & & & & & 0.7 & 0.4 & \\
\hline & Oestriopsis sp. & & & 0.2 & & 0.2 & 0.3 & \\
\hline Coccoliths & Cocolithophorid sp. & & & & & & 2.0 & 0.9 \\
\hline Flagellates & Choanoflagellate sp. & & & & 0.2 & 0.2 & 0.1 & \\
\hline Diversity index & & 1.739 & 1.054 & 0.391 & 0.445 & 0.861 & 1.140 & 1.166 \\
\hline Species evenness & & 0.209 & 0.108 & 0.036 & 0.041 & 0.079 & 0.102 & 0.100 \\
\hline
\end{tabular}




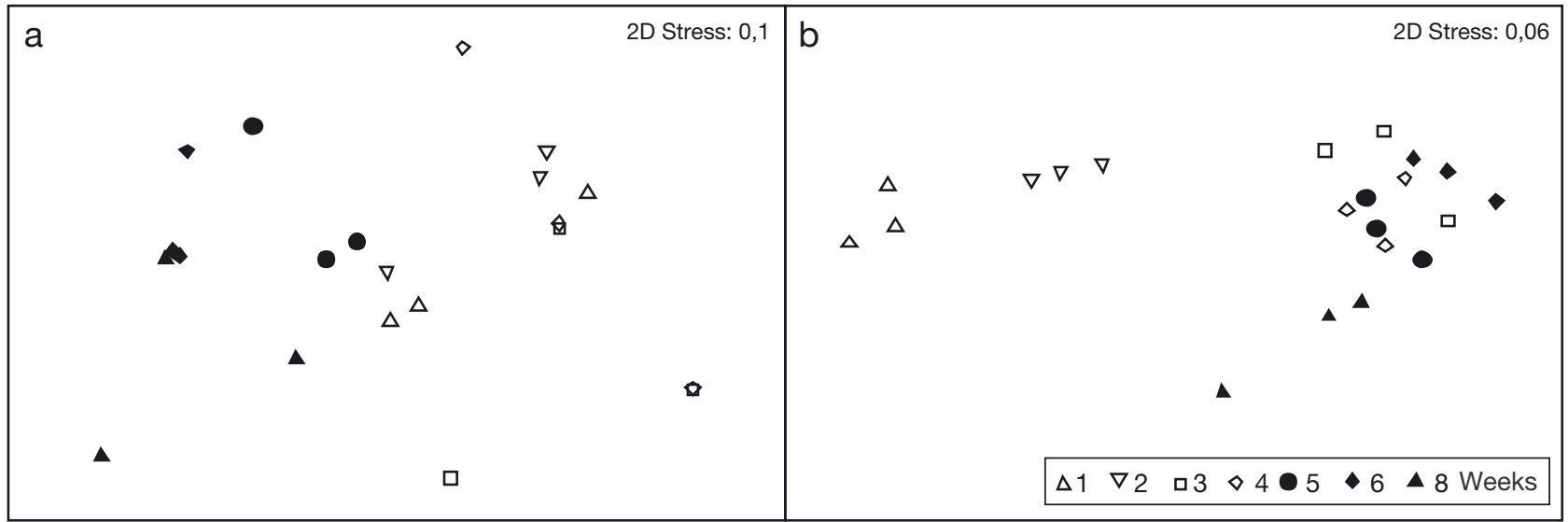

Fig. 1. Multidimensional scale plot of similarity in (a) microalgae and (b) epifauna colonizing biofilm at the different stages of mangrove leaf litter decomposition. Symbols refer to duration of litter decomposition in weeks
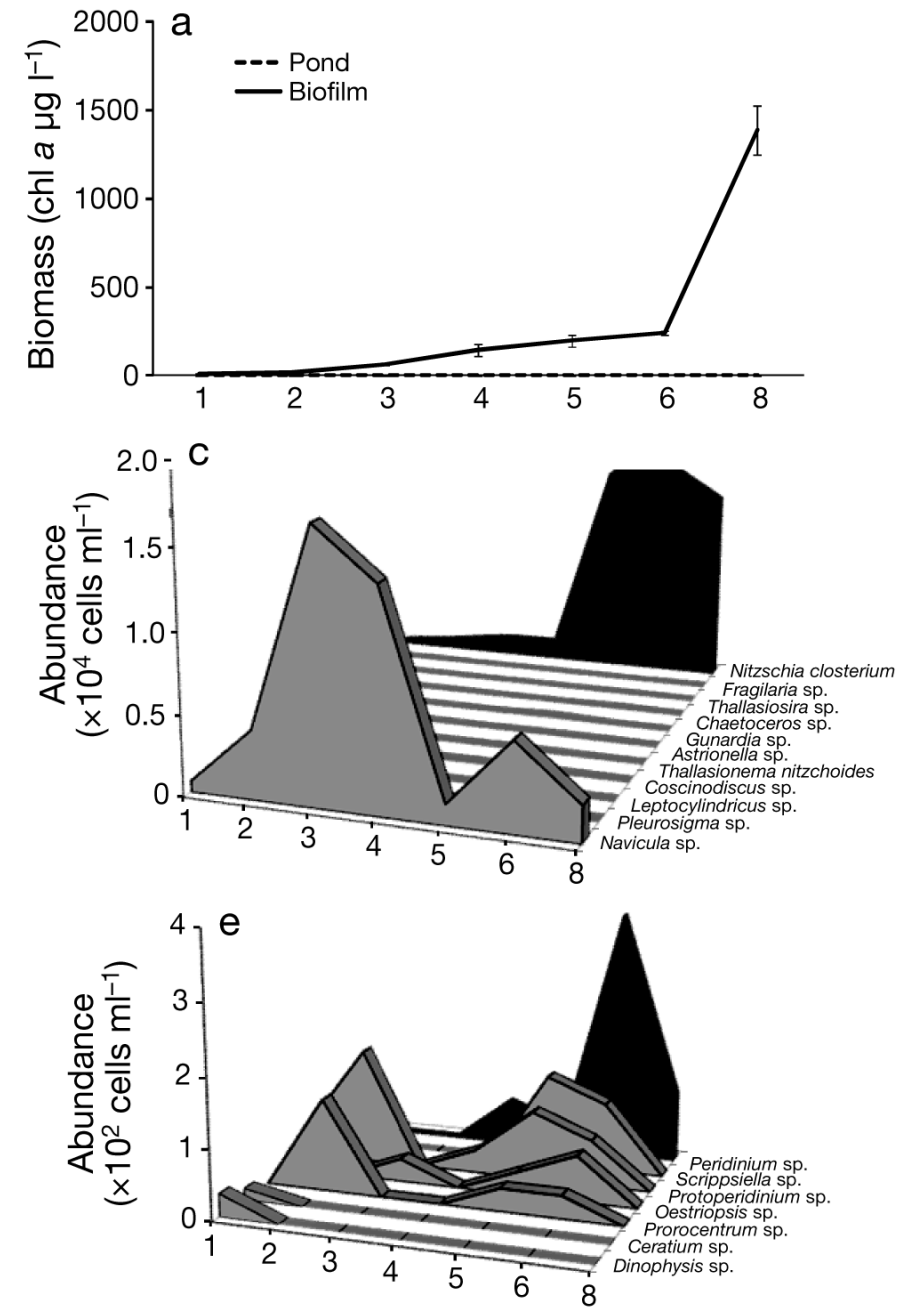

\section{Duration of leaf litter decomposition (wk)}

Fig. 2. Biomass and assemblage of microalgae in biofilm developing on Rhizophora mucronata litter at different stages of decomposition. (a) Biomass of microalgae in the pond water and in biofilm. Absolute abundance of (b) microalgal communities,

(c) diatoms, (d) cyanobacteria, (e) dinoflagellates, and (f) rare microalgal communities 
between 59 and $68 \%$, while Polychaeta dominated during Weeks 4 and 5, with a proportional percentage cover of 90 to $93 \%$; at this stage, the development of biofilm on the litter had the lowest diversity of epifauna and species evenness (Table 2). Concomitantly, the maximum abundance of epifauna was recorded. However, abundance declined as the litter decomposed further towards Weeks 6 and 8 (ANOVA, $F_{6,14}=$ 93.26, $\mathrm{p}<0.05$; Tukey post hoc $\mathrm{p}<0.05)$. Epifauna in the 4 and 5 wk old biofilm was dominated by meiofauna of the lower size class (collected in 38-250 $\mu \mathrm{m}$ sieves) compared to the larger meiofauna (retained in $250 \mu \mathrm{m}-1 \mathrm{~mm}$ sieves) (Fig. 3a). Nematoda were dominant (representing $40 \%$ of the community) in the biofilm developing on litter that had decomposed for 8 wk (Fig. 3b).

\section{Shrimp performance}

\section{Growth rate (SGR)}

PL foraging on the biofilm at the different stages of litter decomposition recorded significantly lower SGR, compared to PL that were fed with compound feed $\left(\mathrm{CP}\right.$; ANOVA $F_{6,14}=30.423, \mathrm{p}<0.05$; Tukey post hoc $\mathrm{p}<0.05)$. However, among the treatments receiving the litter, PL foraging on the biofilm on $4 \mathrm{wk}$ old decomposed litter showed overall better performance (Tukey post hoc $\mathrm{p}<0.05$ ). PL foraging on the biofilm growing on litter that had decomposed for 1, 3, and 6 wk showed reduced growth and in some cases negative SGR. Although PL foraging on the litter that had decomposed for $8 \mathrm{wk}$ showed positive growth, their SGR was not significantly different from the treatments recording negative growth rates and PL in the starvation treatments (Tukey post hoc $\mathrm{p}<0.05$; Fig. 4)

\section{Survival (SR)}

PL fed compound feed (CP) recorded the highest SR (ANOVA, $F_{6,14}=73.85, \mathrm{p}<0.05$; Tukey post hoc $\mathrm{p}<0.05)$. Among the PL foraging on the biofilm on the decomposing litter, PL foraging on the 4 wk old litter recorded the highest mean SR, although they did not differ statistically from PL foraging on the litter decomposed for 1, 3, and $6 \mathrm{wk}$ (Tukey post hoc: $\mathrm{p}>0.05)$. However, pairwise comparisons revealed significantly lower SR in PL foraging on the litter decomposed for $8 \mathrm{wk}$ (Tukey post hoc $\mathrm{p}<0.05$ ). PL in the starvation treatments (NF) recorded the lowest SR of $8.4 \pm 0.9 \%$ (Tukey post hoc $\mathrm{p}<0.05$ ), although they did not differ significantly from the PL foraging on the litter decomposed for $8 \mathrm{wk}$ (Tukey post hoc: $\mathrm{p}>0.05$; Fig. 4).

Table 2. Proportional assemblage ( $P_{i}$ in Eq. 1) of epifauna on biofilm developing on Rhizophora mucronata litter at different stages of decomposition. All values, except diversity index and species evenness, are given in percentages

\begin{tabular}{|c|c|c|c|c|c|c|c|}
\hline & 1 & 2 & 3 & 4 & 5 & 6 & 8 \\
\hline Polychaeta & 4.180 & 6.985 & 8.272 & 92.594 & 90.213 & 39.747 & 35.844 \\
\hline Oligochaeta & 0.965 & 6.704 & 10.154 & 0.016 & 0.038 & 0.202 & \\
\hline Copepoda & 68.328 & 59.165 & 67.773 & 3.722 & 5.026 & 49.958 & 12.035 \\
\hline Nematoda & 23.151 & 22.316 & 3.674 & 3.266 & 4.298 & 8.306 & 39.865 \\
\hline Amphipoda & & & & & 0.003 & & \\
\hline Turbellaria & 3.376 & 4.454 & 8.893 & 0.240 & 0.139 & 0.758 & 6.481 \\
\hline Gastropoda & & & & 0.009 & 0.013 & 0.017 & 0.677 \\
\hline Appendicularia & & & & & 0.002 & & \\
\hline Kinorhyncha & & & 0.018 & 0.009 & & & \\
\hline Cnidaria & & 0.375 & 1.015 & 0.030 & 0.102 & 0.303 & 1.990 \\
\hline Ostracoda & & & 0.055 & 0.079 & 0.161 & 0.388 & 3.095 \\
\hline Bivalvia & & & 0.064 & 0.035 & 0.001 & 0.152 & 0.014 \\
\hline Oikopleura & & & & & 0.002 & & \\
\hline Foraminifera & & & 0.027 & & & 0.168 & \\
\hline Chaetognatha & & & 0.009 & & 0.001 & & \\
\hline Siphonophores & & & & & 0.001 & & \\
\hline Nemertina & & & 0.009 & & & & \\
\hline Holothuroidea & & & 0.027 & & & & \\
\hline Insecta & & & 0.009 & & & & \\
\hline Diversity index & 0.8908 & 1.1718 & 1.1027 & 0.3339 & 0.4102 & 1.0308 & 1.3871 \\
\hline Species evenness & 0.1385 & 0.1529 & 0.1186 & 0.0275 & 0.0349 & 0.0899 & 0.1561 \\
\hline
\end{tabular}




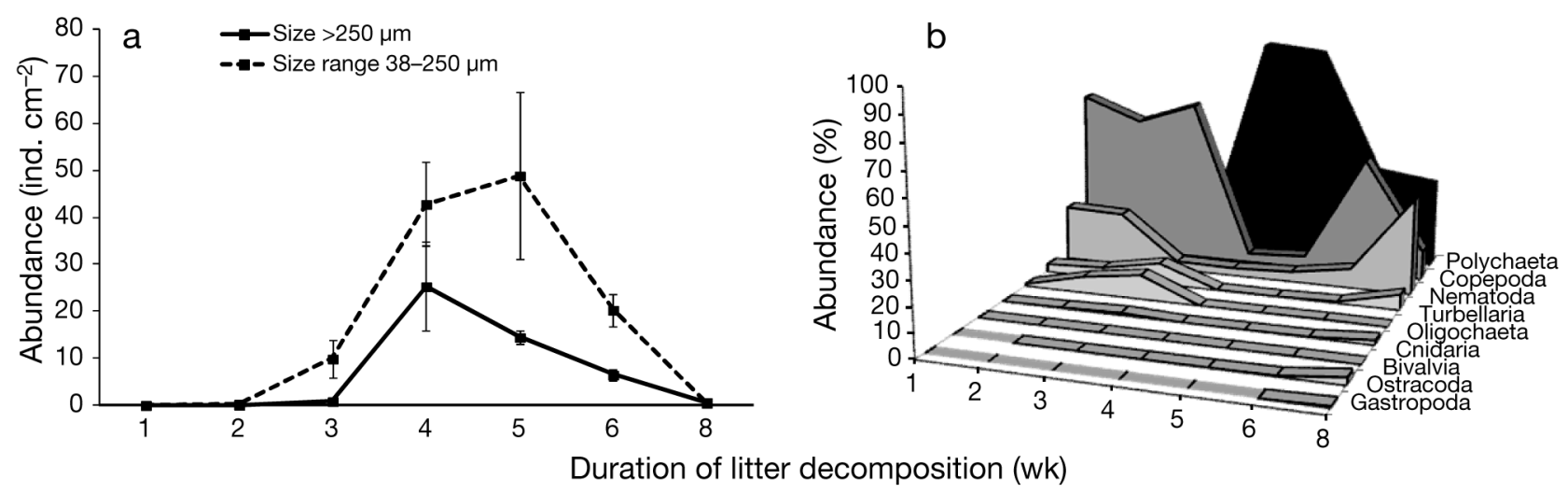

Fig. 3. Abundance and assemblage of the major epifaunal taxa in biofilm developing on Rhizophora mucronata litter at different stages of decomposition. (a) Absolute abundance of epifauna; (b) relative abundance of epifaunal communities
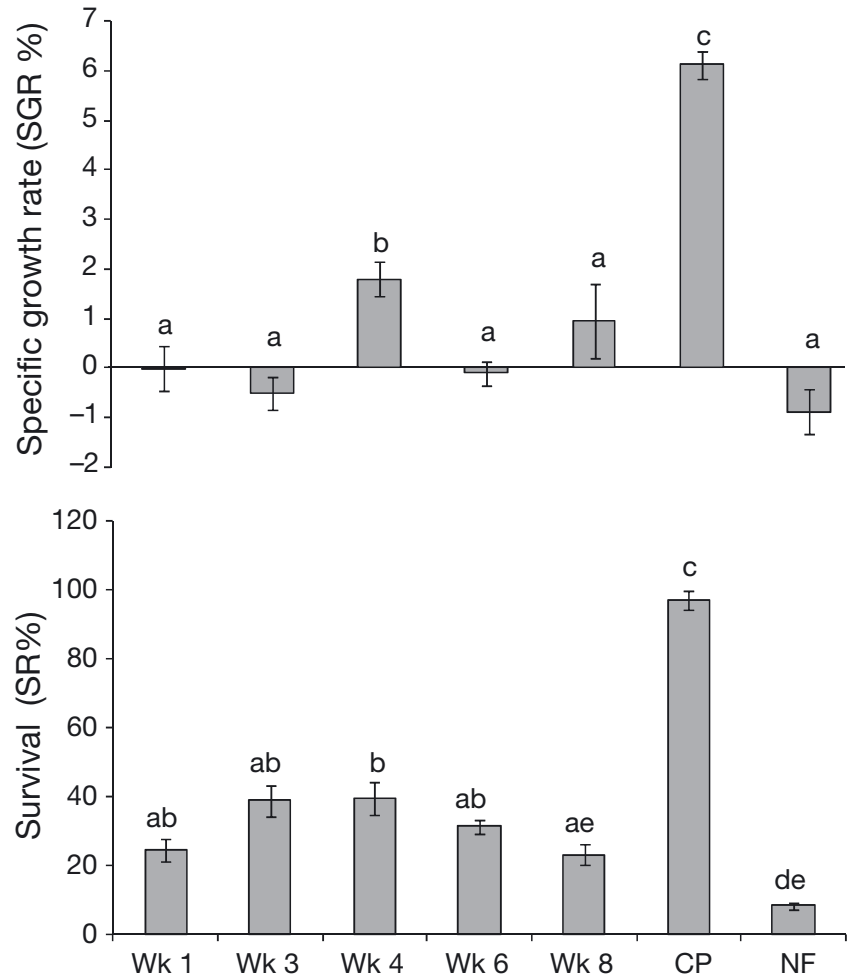

Fig. 4. Performance of Penaeus monodon shrimp post-larvae in different feeding treatments. Wk 1 to Wk 8: shrimp foraging on biofilm on mangrove leaf litter at different stages of decomposition (Weeks 1 to 8); CP: shrimp fed a commercial compound feed, NF: shrimp starved as control. Different letters above the bars indicate significant differences $(p=0.05)$

\section{DISCUSSION}

\section{Microalgae}

In the first $6 \mathrm{wk}$ of the experiment, there was a clear dominance of diatoms but also a shift in the community composition, with Navicula sp. dominating the leaf litter until Week 4 of decomposition. After Week
4, Navicula sp. was replaced by Nitzschia sp. at Weeks 5, 6, and 8. The reason for this shift in diatom species is not understood, although its implication to the diet of PL shrimp could be considerable. Nitzschia sp. has been reported to be richer in proteins (Brown \& Jeffrey 1995) and therefore could present a better source of proteins to the immediate grazers.

Microalgal succession from diatoms to cyanobacteria was prominent at the later stages of the leaf litter decomposition. Cyanobacterial growth can be promoted by high nutrient input (Amado \& Monserrat 2010). The pond water showed a gradual slight increase in TAN after Week 4 of litter incubation. Hence the success of cyanobacteria on the litter may have been a micro-scale bloom triggered by an increase in nutrients leached from the decomposed litter such as the ammonified particulate and dissolved organic nitrogen (Alongi et al. 2000) and phosphorus (Lin \& Sternberg 2007). In addition, the first weeks of biofilm development were characterized by a strong growth of copepods which could feed on the diatoms. Diatoms have a C:N ratio of about 5, and this could influence carbon and nitrogen contents of copepod fecal pellets (Morales 1987, Siuda \& Dam 2010). Copepods that were grazing on diatoms could have released a lot of nutrients, especially ammonium. This may have stimulated the cyanobacterial blooms.

Apart from the increase in cyanobacteria, there was a general decline in the other microalgal species belonging to the diatoms, dinoflagellates, and flagellates during the advanced stages of litter decomposition. Microalgae reached a stationary phase between Weeks 4 and 6 of decomposition and progressed to the death phase during Week 8. The decline of the microalgae may result from grazing by epifauna (Coman et al. 2003). However, the similar decline in epifauna after Week 5 (Fig. 3a) suggests that grazing may not have been the only reason for the decline. 
Decomposing mangrove litter leaches a phenolic compound, viz. tannin (Rajendran \& Kathiresan 2000, Hernes et al. 2001, Lin et al. 2007). Tannin concentrations above $18 \mathrm{mg} \mathrm{l}^{-1}$ inhibit the growth of the microalgae Skeletonema sp. and Dunnaliella sp. in the Gulf of Mexico (Herrera-Silveira \& Ramirez-Ramirez 1996). Tannins leached from the decomposing litter could have had a cumulative negative effect on certain species of microalgae and in this way may have provided space and reduced competition for the proliferation of cyanobacteria.

\section{Epifauna}

Epifauna identified on the biofilm included several juvenile stages of macroinvertebrates such as gastropods, bivalves, crustaceans, polychaetes, insects, and annelid worms which are potential food for PL (Tacon 1996, Rothlisberg 1998). In our study, adult copepods were the major component of the biofilm during the first $3 \mathrm{wk}$ of litter decomposition and mainly consisted of representatives of the order Harpacticoida, which occur in sediments but are also very diverse in epiphytic communities such as on seagrass leaves (De Troch et al. 2003). Juvenile stages of copepods (nauplius larvae), egg cocoons of polychaetes and oligochaetes, and bivalve trochophore and veliger larvae, although enumerated together with the adult species, were possible contributors to the increase in epifauna in the size range of 38 to $250 \mu \mathrm{m}$ which dominated the 4 and $5 \mathrm{wk}$ old biofilm. The increase in juvenile stages suggests recruitment at this phase of the decomposition process. The increase in polychaetes after Week 3 suggests that at this stage of litter decomposition, polychaetes increasingly contribute to the shrimp food (Fig. 3b). According to our previous study (Gatune et al. 2012), litter decomposed for 3 and 4 wk supported a climax microbial abundance and essential fatty acids which may nutritionally influence a healthy assemblage of epifauna. At this stage of litter decomposition, there is also a large pool of nitrogen, amino sugars, and amino acids (Rajendran \& Kathiresan 2000) which would nourish the primary trophic levels occupied by bacteria and microalgae. These microbiota are potential food sources for the epifauna (Woitchik et al. 1997). According to our previous study (Gatune et al. 2012), PL that were stocked in litter were isotopically closer to periphytic biofilm associated with mangrove litter in comparison to PL from bare mangrove zones and open creek habitats. Although the present experiment did not include an isotopic assessment to prove the actual uptake of the prey items by PL, the observation from Gatune et al. (2012) justifies this assumption.

The decline in the abundance of epifauna after the recruitment stage (Weeks 4 and 5) could be due to the reduced survival of juveniles advancing into the adult stages. Reduced supply of quality food because of the decline and aging of diatoms concomitant with an increase of non-palatable cyanobacteria could be the main reasons. Litter decomposed for more than 4 wk could be characterized by low levels of reduced amino sugars and amino acids (Rajendran \& Kathiresan 2000, Tremblay \& Benner 2006). On the other hand, tannins leached from decomposing litter can form complexes with proteins and enzymes leading to antimicrobial properties (Lin et al. 2007) and immobilize nutrients such as nitrogen and phosphorus (Lin \& Sternberg 2007). Such chemical modifications can make decomposing mangrove litter insufficient to support a climax community of microbiota which could serve as an important food source for the epifauna (De Mesel et al. 2004, Pascal et al. 2008a,b, Wieltschnig et al. 2008). Tannins can also impart a direct negative effect on epifauna such as meiofauna (Alongi 1987) and macrofauna (Dittmann 2001).

\section{Performance of post-larval shrimp foraging on biofilm}

PL foraging on biofilm of litter decomposed for a period of less than $3 \mathrm{wk}$ appeared to experience retarded growth. This scenario was also repeated in the PL foraging on 6 wk old litter. A notable improvement in growth and survival was observed in PL foraging on 4 wk old litter. Growth performance of PL can be predicted from quality and/or palatability of food which may be influenced by artificial formulation or favorable environmental conditions. For instance, PL fed CP feed had much improved growth and survival. In the present case, the results of the PL fed with biofilm could not have been affected by underfeeding, since remnant biofilm food was observed. Furthermore, the differences observed especially in SGRs in PL fed with biofilm were clearly separated statistically.

The CP feed, which acted as a reference feed, was specially formulated to provide target nutrients which are essential for improved growth performance (Hertrampf \& Piedad-Pascual 2000, Lavens \& Sorgeloos 2000). The use of natural diets in this study did not necessarily provide a straightforward solution towards improving the commercial diet. However, in 
aquaculture systems, the contribution of natural diets in improving commercial diets may be noticed in situations of supplementary feeding and ecological health consequences which were not tested in the present study. The contribution may not necessarily be immediate but may have a far reaching positive consequence in the economic and health aspects of aquatic organisms under culture. The climax quality microalgal and epifaunal community during Weeks 4 and 5 may have provided PL with a rich source of nutrition, enabling them to withstand adverse water quality conditions such as chemical oxygen demand, tannins, and hydrogen sulfide $\left(\mathrm{H}_{2} \mathrm{~S}\right)$, which are common in decomposing mangrove litter and have a negative effect on shrimp growth (Hai \& Yakupitiyage 2005). Later PL stages, just like the initial stages, could have been affected by scarcity of quality food with a consequential deterioration in health.

\section{Potential effect of microalgae and epifauna on post-larval shrimp growth and survival}

Apart from the diatoms Chaetoceros sp. and Thalassiosira sp. which occurred in small proportions in the biofilm developed on the litter decomposed for 1 and $5 \mathrm{wk}$ (Table 1), the species of microalgae constituting the biofilm grown in these experiments differed from the microalgal species commonly used in the commercial culture of shrimp (e.g. diatoms Chaetoceros sp., Skeletonema sp., and Thalassiosira sp.). However, non-diatom microalgae such as prymnesiophytes (Isochrysis sp., Pavlova sp.), chlorophytes (Tetraselmis sp., Dunaliella sp., Nannochloris sp.), eustigmatophytes (Nannochloropsis sp.), and cryptophytes (Chroomonas sp.) are also commonly used in aquaculture (Brown \& Miller 1992, Brown \& Farmer 1994, Borowitzka 1997). In a microcosm study by Brown \& Jeffrey (1995), Nitzschia closterium was found to be richest in proteins ( $38 \%$ content) compared to 6 other diatoms of the genera Navicula, Skeletonema, Lauderia, and Cylindrotheca. The ecological role of the dominating diatoms on the less decomposed litter cannot be ignored given the importance of diatoms in the energy transfer to the consumer trophic levels. For instance, the characteristic fatty acid composition of diatoms is readily distinguishable from those of other microalgal groups (Ying et al. 2000). Diatoms are typically rich in PUFAs such as eicosapentaenoic acid (EPA, 20:5 $\omega 3$ ) (Parrish et al. 2000). Certain fatty acids such as the PUFAs, highly unsaturated fatty acids, phospholipids, and sterols affect reproduction, growth, metamorphosis of crustacean larvae to juveniles, survival, and resilience to stressful conditions (Read 1981, Bell et al. 1984, Lavens \& Sorgeloos 2000). The nutritional quality of diatoms may deteriorate at the advanced age. While comparing 3 growth phases in 4 marine diatoms, among them N. closterium and Chaetoceros gracilis, Liang \& Mai (2005) observed that saturated and monounsaturated fatty acids increased while the PUFAs decreased with culture age.

PL foraging on litter decomposed for 4 wk may also have benefited from the ample food supply from the increased recruitment of epifauna. The low species diversity and evenness of epifauna and the high abundance of copepods and polychaetes observed at this stage (Fig. 3b) emphasize the ecological importance. Zooplankton and epibenthos contribute to the nutrition of PL in aquaculture installations (Chen \& Chen 1992). The establishment of an abundant assemblage of epifauna is therefore an important prerequisite to stocking (Tacon 1996, Coman et al. 2003) and can be part of the supplementary feeds that can directly be consumed by cultured shrimp. Such natural food items include insects, annelid worms, crustaceans, and mollusks (Tacon 1996). Meiofauna and small macrofauna can constitute a major food source for juvenile fish and shrimp (Dittmann 2001). Rothlisberg (1998) and Hill \& Wassenberg (1987) observed that the diet of juvenile and adult shrimp consisted of a wide variety of zoobenthos and macroinvertebrates (gastropods, bivalves, crustaceans, and polychaetes).

PL foraging on the 6 and 8 wk old biofilm may also have been adversely affected by the replacement of diatoms by cyanobacteria. In the present study, the cyanobacteria Microcystis sp. was dominant; it produces a potent hepatotoxin, a microcystin that is also produced by a number of planktonic cyanobacterial genera such as Anabeana, Anabaenopsis, Nostoc, and Planktothrix (Oscillatoria) (Amado \& Monserrat 2010) and other bioactive metabolites with potential to degrade the nutritional status of aquaculture species (inhibitors of proteases and grazer deterrents) (Smith et al. 2008). The reduced epifaunal abundance could also have caused reduced growth and survival of PL foraging in the litter decomposed for more than $4 \mathrm{wk}$.

\section{CONCLUSION}

The present study underlines the ecological importance of the periphytic biofilm developed on the mangrove litter decomposed for $4 \mathrm{wk}$ as an important 
food and stage of development in supporting PL. Biofilm of high food quality is fully developed and is dominated by diatoms, polychaetes, harpacticoid copepods, and oligochaetes. The ecological function of decomposing litter in providing quality natural food to PL is limited if retained in the pond water beyond a period of $4 \mathrm{wk}$. This is illustrated by the collapse of the epifauna and subsequent colonization by cyanobacteria of low nutritional quality. This needs to be considered when controlling the residence time of decomposing mangrove litter in shrimp ponds.

Acknowledgements. C.G. thanks the Flemish InterUniversity Council (VLIR) for the financial support to follow an international PhD program in Biology at Ghent University, Belgium, and an additional short research stay (SRS) scholarship to prepare this manuscript for publication. We thank Dr. C. Mahika, Director of Aquaculture, G. Vageri and R. Ari of Alphakrust, Tanzania, for facilitating export and donating the post-larval shrimp. We thank KMFRI laboratory technicians James Kilonzi, Eric Magara, Mary Mkonu, George Onduso, Mary Adungosi, Mwendwa Mbaluka, and the youth and community members of the Majaoni silvofishery project, Kenya, for their field assistance. M.D.T. acknowledges the Special Research Fund of Ghent University (BOFGOA 01GA1911W). We thank the anonymous reviewers for their constructive remarks that helped us to improve an earlier version of the manuscript.

\section{LITERATURE CITED}

- Alongi DM (1987) The influence of mangrove-derived tannins on intertidal meiobenthos in tropical estuaries. Oecologia 71:537-540

Alongi DM, Johnston DJ, Xuan TT (2000) Carbon and nitrogen budgets in shrimp ponds of extensive mixed shrimpmangrove forestry farms in the Mekong Delta, Vietnam. Aquacult Res 31:387-399

Amado LL, Monserrat JM (2010) Oxidative stress generation by microcystins in aquatic animals: why and how. Environ Int 36:226-235

Azim ME, Wahab MA (2005) Periphyton based pond polyculture. In: Azim ME, Verdegem MCJ, van Dam AA, Beveridge MCM (eds) Periphyton: ecology, exploitation and management. CABI Publishing, Wallingford, p 207-222

> Bell JD, Pollard DA, Burchmore JJ, Pease BC, Middleton MJ (1984) Structure of a fish community in a temperate tidal mangrove creek in Botany Bay, New South Wales. Aust J Mar Freshw Res 35:33-46

> Borowitzka M (1997) Microalgae for aquaculture: opportunities and constraints. J Appl Phycol 9:393-401

Bouillon S, Koedam N, Raman AV, Dehairs F (2002) Primary producers sustaining macroinvertebrate communities in intertidal mangrove forests. Oecologia 130:441-448

> Brown M, Farmer C (1994) Riboflavin content of six species of microalgae used in mariculture. J Appl Phycol 6:61-65

Brown MR, Jeffrey SW (1995) The amino acid and gross composition of marine diatoms potentially useful for mariculture. J Appl Phycol 7:521-527

Brown M, Miller K (1992) The ascorbic acid content of eleven species of microalgae used in mariculture. J Appl Phycol 4:205-215

Burford MA (1997) Phytoplankton dynamics in shrimp ponds. Aquacult Res 28:351-360

Burford MA, Thompson PJ, McIntosh RP, Bauman RH, Pearson DC (2003) Nutrient and microbial dynamics in highintensity, zero-exchange shrimp ponds in Belize. Aquaculture 219:393-411

Busacker GP, Adelman TR, Goolish EM (1990) Growth. In: Schreck CB, Moyle PB (eds) Methods for fish biology. American Fishery Society, Bethesda, MD, p 363-387

> Casé M, Leça EE, Leitão SN, Sant Anna EE, Schwamborn R, Travassos de Moraes Junior A (2008) Plankton community as an indicator of water quality in tropical shrimp culture ponds. Mar Pollut Bull 56:1343-1352

Chen YLL, Chen HY (1992) Juvenile Penaeus monodon as effective zooplankton predators. Aquaculture 103:35-44

Clarke KR, Gorley RN (2006) PRIMER v6. User manual/tutorial. PRIMER-E, Plymouth

> Coman FE, Connolly RM, Preston NP (2003) Zooplankton and epibenthic fauna in shrimp ponds: factors influencing assemblage dynamics. Aquacult Res 34:359-371

> D'Souza FML, Kelly GJ (2000) Effects of a diet of a nitrogenlimited alga (Tetraselmis suecica) on growth, survival and biochemical composition of tiger prawn (Penaeus semisulcatus) larvae. Aquaculture 181:311-329

> Dall W, Smith DM, Moore LE (1991) Biochemical composition of some prey species of Penaeus esculentus Haswell (Penaeidae: Decapoda). Aquaculture 96:151-166

> De Mesel I, Derycke S, Moens T, Van De Gucht K, Vincx M, Swings J (2004) Top-down impact of bacterivorous nematodes on the bacterial community structure: a microcosm study. Environ Microbiol 6:733-744

De Troch M, Fiers F, Vincx M (2003) Niche segregation and habitat specialisation of harpacticoid copepods in a tropical seagrass bed. Mar Biol 142:345-355

> Dittmann S (2001) Abundance and distribution of small infauna in mangroves of Missionary Bay, North Queensland, Australia. Rev Biol Trop 49:535-544

Eaton $\mathrm{AD}$, Clesceri LS, Rice EW, Greenberg AE, Franson $\mathrm{AH}$ (eds) (2005) Standard methods for the examination of water and waste water. American Public Health Association, Washington, DC

Gatune C, Vanreusel A, Cnudde C, Ruwa R, Bossier P, de Troch M (2012) Decomposing mangrove litter supports a microbial biofilm with potential nutritive value to penaeid shrimp post larvae. J Exp Mar Biol Ecol 426-427: 28-38

Granger S, Lizumi H (2001) Water quality measurement methods for seagrass habitat. In: Short FT, Coles RG (eds) Global seagrass research methods. Elsevier, Amsterdam, p 402-404

> Hai TN, Yakupitiyage A (2005) The effects of the decomposition of mangrove leaf litter on water quality, growth and survival of black tiger shrimp (Penaeus monodon Fabricius, 1798). Aquaculture 250:700-712

Hernes PJ, Benner R, Cowie GL, Goni MA, Bergamaschi BA, Hedges JL (2001) Tannin diagenesis in mangrove leaves from a tropical estuary; a novel molecular approach. Geochim Cosmochim Acta 65:3109-3122

> Herrera-Silveira JA, Ramirez-Ramirez J (1996) Effects of natural phenolic material (tannin) on phytoplankton growth. Limnol Oceanogr 41:1018-1023

Hertrampf JW, Piedad-Pascual F (2000) Handbook of ingredients for aquaculture feeds. Kluwer, Dordrecht 
Hill BJ, Wassenberg TJ (1987) Feeding behaviour of adult tiger prawns, Penaeus esculentus, under laboratory conditions. Aust J Mar Freshw Res 38:183-190

Lavens P, Sorgeloos P (2000) Experiences on importance of diet for shrimp postlarval quality. Aquaculture 191: 169-176

Liang Y, Mai K (2005) Effect of growth phase on the fatty acid compositions of four species of marine diatoms. J Ocean Univ China 4:157-162

Lin YM, Sternberg LSL (2007) Nitrogen and phosphorus dynamics and nutrient resorption of Rhizophora mangle leaves in South Florida, USA. Bull Mar Sci 80:159-169

Lin YM, Liu JW, Xiang P, Lin ZH, Sternberg L, Da SL (2007) Tannins and nitrogen dynamics in mangrove leaves at different age and decay stages (Jiulong River Estuary, China). Hydrobiologia 583:285-295

Morales CE (1987) Carbon and nitrogen content of copepod faecal pellets: effect of food concentrations and feeding behavior. Mar Ecol Prog Ser 36:107-114

> Nunes AJP, Parsons GJ (2000) Effects of the southern brown shrimp, Penaeus subtilis, predation and artificial feeding on the population dynamics of benthic polychaetes in tropical pond enclosures. Aquaculture 183:125-147

Parrish CC, Abrajano TA, Budge SM, Helleur RJ, Hudson ED, Pulchan K, Ramos C (2000) Lipid and phenolic biomarkers in marine ecosystems: analysis and applications. In: Wangersky P (ed) The handbook of environmental chemistry, Part D. Marine chemistry. Springer, Berlin, p 193-233

Pascal P, Dupuy C, Richard P, Niquil N (2008a) Bacterivory in the common foraminifer Ammonia tepida: isotope tracer experiment and the controlling factors. J Exp Mar Biol Ecol 359:55-61

Pascal P, Dupuy C, Richard P, Rzeznik-Orignac J, Niquil N (2008b) Bacterivory of a mudflat nematode community under different environmental conditions. Mar Biol 154: 671-682

Preston NP, Burford MA, Coman FE, Rothlisberg PC (1992) Natural diet of larval Penaeus merguiensis (Decapoda: Penaeidae) and its effect on survival. Mar Biol 113: 181-191

Preston NP, Burford MA, Stenzel DJ (1998) Effects of Trichodesmium spp. blooms on penaeid prawn larvae. Mar Biol 131:671-679

Primavera JH (1996) Stable carbon and nitrogen isotope ratios of penaeid juveniles and primary producers in a riverine mangrove in Guimaras, Philippines. Bull Mar Sci 58:675-683

Primavera JH (1998) Tropical shrimp farming and its sustainability. In: De Silva S (ed) Tropical mariculture. Academic Press, New York, NY, p 257-289

Rajendran N, Kathiresan K (2000) Biochemical changes in decomposing leaves of mangroves. Chem Ecol 17:

Editorial responsibility: Erik Kristensen, Odense, Denmark
91-102

Rajendran N, Kathiresan K (2004) How to increase juvenile shrimps in mangrove waters. Wetl Ecol Manag 12: 179-188

> Rajendran N, Kathiresan K (2007) Microbial flora associated with submerged mangrove leaf litter in India. Rev Biol Trop 55:393-400

Read GHL (1981) The response of Penaeus indicus (Crustacea: Penaeidea) to purified and compounded diets of varying fatty acid composition. Aquaculture 24:245-256

Ronnback P, Macia A, Almqvist G, Schultz L, Troell M (2002) Do penaeid shrimps have a preference for mangrove habitats? Distribution pattern analysis on Inhaca island, Mozambique. Estuar Coast Shelf Sci 55:427-436

> Rothlisberg PC (1998) Aspects of penaeid biology and ecology relevance to aquaculture: a review. Aquaculture 164:49-65

Schwamborn R, Ekau W, Voss M, Saint-Paul U (2002) How important are mangroves as a carbon source for decapod crustacean larvae in a tropical estuary? Mar Ecol Prog Ser 229:195-205

- Shannon CE (1948) A mathematical theory of communication. Bell Syst Tech J 27:623-656

Siuda ANS, Dam HG (2010) Effects of omnivory and predator-prey elemental stoichiometry on planktonic trophic interactions. Limnol Oceanogr 55:2107-2116

Smith JL, Boyer GL, Zimba PV (2008) A review of cyanobacterial odorous and bioactive metabolites: impacts and management alternatives in aquaculture. Aquaculture 280:5-20

Tacon AGJ (1996) Feed formulation and evaluation for semiintensive culture of fishes and shrimps in the tropics. In: Santiago CB, Coloso RM, Millamena OM, Borlongan IG (eds) Feeds for small-scale aquaculture. Proc Natl Seminar-Workshop on Fish Nutrition and Feeds. SEAFDEC Aquaculture Department, Tigbauan, Iloilo, Philippines, p 29-43

> Tremblay L, Benner R (2006) Microbial contributions to Nimmobilization and organic matter preservation in decaying plant detritus. Geochim Cosmochim Acta 70: 133-146

Wieltschnig C, Fischer UR, Velimirov B, Kirschner AKT (2008) Effects of deposit-feeding macrofauna on benthic bacteria, viruses, and protozoa in a silty freshwater sediment. Microb Ecol 56:1-12

Woitchik AF, Ohawa B, Kazungu JM, Rao RG, Goeyens L, Dehairs F (1997) Nitrogen enrichment during decomposition of mangrove leaf litter in an East African coastal lagoon (Kenya): relative importance of biological nitrogen fixation. Biochemistry 39:15-35

> Ying L, Kang-sen M, Shi-chun S (2000) Total lipid and fatty acid composition of eight strains of marine diatoms. Chin J Oceanol Limnol 18:345-349

Submitted: January 8, 2014; Accepted: July 8, 2014 Proofs received from author(s): September 3, 2014 